\title{
Mapping quantitative trait loci for milk production and genetic polymorphisms of milk proteins in dairy sheep
}

\author{
Francis BARILlET $^{\mathrm{a} *}$, Juan-José ARRANZ ${ }^{\mathrm{b}}$, Antonello CARTA $^{\mathrm{c}}$ \\ a Station d'amélioration des animaux, Institut national de la recherche agronomique, BP 27, \\ 31326 Castanet-Tolosan Cedex, France \\ ${ }^{\mathrm{b}}$ Universidad de Leon, Departamento de Produccion Animal, 24071 Leon, Spain \\ ${ }^{c}$ Istituto Zootecnico e Caseario per la Sardegna, 07040 Olmedo, Italy
}

(Accepted: 5 October 2004)

\begin{abstract}
In this paper, we present recent advances in the molecular dissection of complex traits in dairy sheep and discuss their possible impact on breeding schemes. In the first step, we review the literature data on genetic polymorphisms and the effects of sheep $\alpha_{\mathrm{s} 1}$-casein and $\beta$-lactoglobulin loci. It is concluded that the results are rather inconsistent and cannot be used in dairy sheep selection. In a second step, we describe the strategy implemented in France, Italy and Spain taking advantage of the genetic maps for QTL detection. These studies were part of a European project, called "genesheepsafety", which investigated both milk production and functional traits. Preliminary QTL results are presented for production traits.
\end{abstract}

dairy sheep / milk proteins / genetic polymorphisms / QTL / milk production

\section{INTRODUCTION}

Dairy sheep have been traditionally farmed in Europe, especially in Mediterranean countries in a wide range of local production systems combined to a great genetic diversity [8]. Most Mediterranean dairy sheep are dual purpose, with incomes originating from both meat (milk-fed lambs) and milk, with milk being processed into high quality cheese. Since milk sales represent 65 to $75 \%$ of farm income, increasing milk yield is still the most profitable objective for most breeds $[26,37]$. The most frequent breeding strategy corresponds to the selection of the local breeds for milk yield and composition within their specific area and production system [2].

Moreover, due to the evolution of the European consumers demand for typical products, and for higher quality and safety, dairy sheep also now have

*Corresponding author: Barillet@toulouse.inra.fr 
to be improved for new traits of economic importance, which has rapidly increased in recent years. These new traits, such as udder morphology and milkability $[15,19,36]$, functional longevity, or resistance to diseases like mastitis $[3,22,46]$, are related to the reduction of production costs and the increase of the quality and safety of the products. When compared to cattle, dairy sheep have some important characteristics: (i) the use of artificial insemination is more or less limited and natural mating plays an important role in reproduction; and (ii) the individual recording of any trait is much more costly due to the lower individual income per ewe. Under these conditions, applying markerassisted selection (MAS) or gene-assisted selection (GAS), either to speed up selection of routinely measured traits or to implement selection for traits costly to record, seems to be attractive in dairy sheep.

Before implementing MAS, or GAS which is economically more realistic in dairy sheep, accurate molecular knowledge is required for traits of interest. In this paper, we review the results on genetic polymorphisms of milk proteins, mainly investigated in the 1990s after the spectacular results observed in goats. Then, we present the strategy implemented in several countries, taking advantage of the genetic marker maps for QTL detection. In the European Union, a series of regional projects started at the end of the 1990s to analyse the genetic variability of economically relevant traits. Most investigations focused on production traits due to the lack of phenotypic information on functional traits. Some of these projects were federated in the EC-funded Genesheepsafety project to investigate both production and functional traits. This paper presents some preliminary QTL results for production traits in three dairy sheep populations involved in this project.

\section{GENETIC POLYMORPHISMS OF MILK PROTEINS}

Several milk protein polymorphisms have been considered as potential tools for selection of dairy ruminants. DNA-based molecular methods have made genotyping of animals of any age and sex for milk protein genes possible, thus providing a potentially more efficient and flexible selection tool than protein electrophoretical genotyping on milk. Selection efficiency, however, depends on allelic frequencies in the breeds and on the effect of these polymorphisms on dairy traits and technological properties of milk. For dairy sheep, research on the genetic polymorphisms of caseins and whey proteins is still limited to $\alpha_{\mathrm{s} 1^{-}}$ casein and $\beta$-lactoglobulin loci, giving less conclusive results than in goats.

The casein fraction of ruminant milk consists of four caseins, namely $\alpha_{\mathrm{s} 1}$, $\alpha_{\mathrm{s} 2}, \beta$ and $\kappa$, encoded by four clustered genes located on chromosome 6 of 
Table I. Allelic frequencies at the $\alpha_{\mathrm{s} 1}$-casein and the $\beta$-lactoglobulin loci in samples of some European dairy sheep breeds, from $[1,6,29,38-41,45]$.

\begin{tabular}{|c|c|c|c|c|c|c|}
\hline \multirow{3}{*}{ Breed } & \multirow{3}{*}{ Country } & \multirow{3}{*}{$n$} & \multicolumn{4}{|c|}{ Allele frequencies } \\
\hline & & & \multicolumn{2}{|c|}{$\alpha_{\mathrm{s} 1}$-casein } & \multicolumn{2}{|c|}{$\beta$-lactoglobulin } \\
\hline & & & $\mathrm{D}$ allele ${ }^{(1)}$ & Normal & $\mathrm{A}$ & B \\
\hline Lacaune & France & $1054^{(2)}$ & 0.007 & 0.993 & 0.643 & 0.357 \\
\hline Lacaune & France & $517^{(3)}$ & 0.001 & 0.999 & 0.627 & 0.373 \\
\hline Lacaune & France & $992^{(2)}$ & - & - & 0.565 & 0.435 \\
\hline Manech (blondfaced) & France & $222^{(2)}$ & 0.000 & 1.000 & 0.473 & 0.527 \\
\hline Massa & Italy & 54 & - & - & 0.53 & 0.47 \\
\hline Sarda & Italy & $2700^{(2)}$ & 0.027 & 0.973 & & \\
\hline Sarda & Italy & $652^{(4)}$ & 0.028 & 0.972 & & \\
\hline Sarda & Italy & $2957^{(2)}$ & & & 0.274 & 0.726 \\
\hline Churra & Spain & $901^{(2)}$ & - & - & 0.325 & 0.675 \\
\hline Merino & Spain & $168^{(4)}$ & 0.009 & 0.991 & - & - \\
\hline Merino & Spain & $340^{(4)}$ & - & - & 0.58 & 0.41 \\
\hline Manchega & Spain & $238^{(4)}$ & 0.000 & 1 & 0.32 & 0.68 \\
\hline Segureña & Spain & $50^{(4)}$ & 0.000 & 1 & 0.67 & 0.33 \\
\hline
\end{tabular}

cattle, sheep and goats $[9,30]$. Two $\alpha_{s 1}$-cas variants, "Normal" and "Welsh" were first detected [31] followed by five variants ( $A$ to $E$ ) [16]. But only the Welsh, subsequently denoted $D$ variant, has been related to a decrease in casein content and renneting properties [41,42]. This $\alpha_{s 1}$-cas unfavourable $D$ allele is rare in all analysed breeds (Tab. I), with frequencies ranging from 0 to 0.03 , and therefore has little potential for selection.

Three genetic variants $(A, B$, and $C$ ) of ovine $\beta$-lactoglobulin have been described [24]. But the $\beta$ - $\lg C$ allele has been found only in the Merinos type breeds and at a low frequency. The results reported on the effect of the other $A$ and $B$ polymorphisms on production traits and cheese-making properties are inconsistent. On the one hand, Caroli et al. [10] and Fraghi et al. [25] reported a positive effect of the $B$ allele on milk yield in the Sarda breed, while Lopez-Galvez et al. [34] found that the $\beta$-lg $A A$ genotype milk had better cheese-making properties than $\beta$-lg $B B$ or $A B$ genotypes in the Manchega breed. Similarly, Gutierrez-Gil et al. [29] found that $A A$ homozygous animals showed a higher individual cheese yield than $A B$ or $B B$ ewes in the Churra 
breed. On the other hand, Recio et al. [43] did not report any difference in renneting properties between the different genotypes. Pietrolà et al. [40] did not find any direct effect or linkage between milk yield and $\beta$-lactoglobulin genotype using two independent designs: a first sample of 2957 primaparous Sarda ewes in 132 recorded flocks and a granddaughter family (with a heterozygous $A B$ sire, 14 sons and 512 daughters). Finally, a trial in the Lacaune breed based on 5 heterozygous $\beta$ - $\lg A B$ sire families and 992 daughters did not show any direct effect or association between $\beta$-lg alleles and production traits, i.e. milk, fat, and protein yields, and fat and protein contents (Barillet, unpublished results). The lack of effects found in the most powerful designs suggests that the significant results reported first could be false positives, due to some confounding with environmental effects and the lack of appropriate adjustments. Indeed, some studies were based on individual milk sample measurements unadjusted for days in milk and parity. To conclude, the relations between $\beta$-lg polymorphism and dairy traits or technological properties of milk remain controversial and are generally inconsistent. It is not recommended to use this polymorphism in selection.

\section{MAPPING QUANTITATIVE TRAIT LOCI FOR MILK PRODUCTION}

\subsection{Resource populations of the "Genesheepsafety" project}

Two resource populations are involved in a genome scan for primary QTL detection in dairy sheep: (i) a Sarda $\times$ Lacaune backcross population was generated on an experimental farm and recorded for a number of original traits of potential interest in selection; and (ii) a daughter design was used in the Churra breed nucleus flocks to map QTL for routinely recorded traits. Additionally, targeted genome regions or chromosomes known to harbour QTL in dairy cattle or sheep were studied in purebred granddaughter families of French dairy sheep breeds (Basco-Béarnaise, Lacaune and Manech).

\subsubsection{Back-cross Sarda $\times$ Lacaune resource population}

Crosses between breeds allow the exploitation of linkage disequilibrium for genes differing between breeds in order to detect genome regions controlling the traits of interest. The Sarda and Lacaune breeds are the two most numerous Italian and French dairy sheep breeds, and they differ in many traits $[4,12]$. 
An experimental Sarda $\times$ Lacaune backcross population was created in 1999 by IZCS (Italy) and INRA (France) in order to detect QTL for production and functional traits $[11,13]$. In 1998, 14 AI elite Lacaune rams were mated in Italy to Sarda ewes to produce F1 rams. Among these, 10 sons of 10 different Lacaune sires were mated to Sarda ewes to procreate 980 backcross females born in 1999. Family size ranged from 76 to 121. The ewes were bred in an experimental farm of IZCS located in the southern part of Sardinia. They completed their fourth lactation in 2003. During their life, they were recorded for many traits including growth rate, adult body weight and body condition score, reproduction, milk production, conjugated linoleic acid (CLA) content in milk, wool production, udder morphology, milkability, resistance to mastitis, gastrointestinal parasitosis and nasal bot.

\subsubsection{Churra breed resource population}

In outbred populations, daughter and granddaughter designs are used to identify marker-QTL associations in large dairy half-sib families obtained by artificial insemination [50]. The Churra breed is one of the most important dairy sheep in Spain, and the Churra programme is aimed at mapping QTL affecting milk production and functional traits. It takes advantage of medium to large half-sib families obtained by $\mathrm{AI}$ and of genetic evaluations providing accurate estimated breeding values (EBV) used as phenotypes in QTL detection. The daughter design was comprised of 1428 ewes distributed in 11 paternal half-sib families generated by AI in 17 farms. The family size ranged from 69 to 261 with a mean of 130 ewes. All the animals belonged to the nucleus scheme of the Spanish Churra National Breeders (ANCHE) and were routinely on-farm recorded for dairy traits.

\subsubsection{French breed resource population}

The breeding programmes in the Lacaune, Basco-Béarnaise and Manech breeds are based on a large scale artificial insemination and progeny test (640 AI rams tested per year). EBV are obtained routinely for six on-farm recorded traits: milk, fat, and protein yields, fat and protein contents, and somatic cell score (SCS) for mastitis resistance. Evaluations for udder score, prolificacy, and functional longevity are being implemented.

Seven hundred and eighty-three AI rams were involved in a granddaughter design. They were distributed in 22 families (18 in Lacaune, 1 in BascoBéarnaise, 3 in Manech breeds). Family size averaged 36 sons per sire and 
ranged from 24 to 56. The sons were born between 1992 and 2002 and had 89 daughters on average. A preliminary analysis was performed in 2001 using 419 sons and 13 families [47].

\subsection{Microsatellite genotyping of the three resource populations of the "Genesheepsafety" project}

A whole genome scan was undertaken for the first two resource populations with 132 and 175 microsatellites compiled from published marker maps [35]. Microsatellite genotypes were identified using Applied Biosystems' "four dye/one lane" technology on an ABI 377 automatic sequencer.

These panels covered $73 \%$ and $83 \%$ of the autosomal genome for the Sarda $\times$ Lacaune and Churra populations, respectively (Tab. II). The average marker information in backcross Sarda $\times$ Lacaune was 0.53 , ranging from 0.38 to 0.81. In Churra purebred families, average information content over the whole genome was 0.58 , varying from 0.39 to 0.75 according to the chromosome. For the Lacaune and Manech granddaughter designs, 20 microsatellite markers were chosen on seven candidate chromosomes (Tab. II). These regions were selected because their homologous regions in bovines are known to carry QTL affecting dairy traits or SCS.

\subsection{Preliminary QTL detection results of the "genesheepsafety" project for production traits}

Preliminary results have been recently published for first lactation traits in the Sarda $\times$ Lacaune back-cross design [11, 13], for 11 markers of chromosomes OAR9 (complete design) [20] and OAR6 (726 ewes from eight families) in Churra sheep [23], and for 13 of the 22 granddaughter Lacaune and Manech families focusing on seven candidate chromosomal regions [47].

\subsubsection{Phenotypes}

In the Sarda $\times$ Lacaune backcross design, individual first lactations of 975 ewes were analysed considering fixed effects of lactation length, age at lambing, number of lambs born and flock $\times$ year interaction. Solutions were obtained from the GLM procedure of SAS ${ }^{\circledR}$. In Churra sheep, the dependent variable was the yield deviation (YD), defined as the weighted average of the ewe's performances adjusted for fixed environmental effects [20]. Similarly, 
Table II. Length and information content (IC) of linkage groups per chromosome, according to resource populations of the "Genesheepsafety" project.

\begin{tabular}{|c|c|c|c|c|c|c|c|}
\hline \multicolumn{2}{|c|}{ Chrom. Length $\mathrm{cM}^{1}$} & \multicolumn{2}{|c|}{$\begin{array}{c}\text { Sarda } \times \text { Lacaune } \\
(\mathrm{BC})\end{array}$} & \multicolumn{2}{|c|}{$\begin{array}{l}\text { Churra } \\
\text { (DD) }\end{array}$} & \multicolumn{2}{|c|}{$\begin{array}{c}\text { Lacaune \& Manech } \\
\text { (GDD) }\end{array}$} \\
\hline & & $\begin{array}{c}\text { Nb. } \\
\text { markers } \\
(\% \\
\text { Coverage })\end{array}$ & $\begin{array}{c}\mathrm{IC} \\
\text { (average } \\
\% \text { ) }\end{array}$ & $\begin{array}{c}\mathrm{Nb} . \\
\text { markers } \\
(\% \\
\text { Coverage })\end{array}$ & $\begin{array}{c}\mathrm{IC} \\
\text { (average } \\
\%)\end{array}$ & $\begin{array}{c}\text { Nb. } \\
\text { markers } \\
(\% \\
\text { Coverage })\end{array}$ & $\begin{array}{c}\mathrm{IC} \\
\text { (average } \\
\% \text { ) }\end{array}$ \\
\hline OAR1 & 347.4 & $16(90)$ & 60 & $14(80)$ & 56 & & \\
\hline OAR2 & 308.4 & $12(97)$ & 50 & $11(80)$ & 52 & & \\
\hline OAR3 & 313.4 & $10(78)$ & 52 & $8(75)$ & 49 & & \\
\hline OAR4 & 151.9 & $6(87)$ & 52 & $5(78)$ & 56 & & \\
\hline OAR5 & 156.9 & $3(61)$ & 64 & $8(85)$ & 60 & $4(79)$ & 52 \\
\hline OAR6 & 156.7 & $6(76)$ & 58 & $9(95)$ & 75 & $2(25)$ & 71 \\
\hline OAR7 & 145.9 & $6(68)$ & 38 & $8(95)$ & 62 & & \\
\hline OAR8 & 132.8 & $3(54)$ & 59 & $5(90)$ & 39 & & \\
\hline OAR9 & 126.9 & $5(65)$ & 61 & $8(95)$ & 70 & $2(43)$ & 69 \\
\hline OAR10 & 105.1 & $4(87)$ & 67 & $4(75)$ & 42 & & \\
\hline OAR11 & 112.4 & $4(49)$ & 44 & $5(85)$ & 51 & $3(49)$ & 74 \\
\hline OAR12 & 113.1 & $6(81)$ & 58 & $5(78)$ & 56 & & \\
\hline OAR13 & 128.3 & $5(90)$ & 48 & $6(72)$ & 54 & & \\
\hline OAR14 & 119.9 & $5(79)$ & 81 & $5(80)$ & 64 & & \\
\hline OAR15 & 124.4 & $2(40)$ & 65 & $6(83)$ & 63 & $3(52)$ & 61 \\
\hline OAR16 & 86.2 & $4(81)$ & 62 & $7(90)$ & 70 & $4(80)$ & 81 \\
\hline OAR17 & 130.7 & $4(80)$ & 59 & $7(95)$ & 48 & & \\
\hline OAR18 & 131.5 & $6(70)$ & 51 & $6(85)$ & 56 & & \\
\hline OAR19 & 73.3 & $4(70)$ & 58 & $4(62)$ & 56 & & \\
\hline OAR20 & 89.6 & $3(43)$ & 62 & $6(90)$ & 58 & & \\
\hline OAR21 & 74.2 & $5(79)$ & 66 & $7(85)$ & 62 & & \\
\hline OAR22 & 82.9 & $3(72)$ & 51 & $3(50)$ & 54 & $2(24)$ & 84 \\
\hline OAR23 & 95.5 & $2(38)$ & 66 & $5(95)$ & 62 & & \\
\hline OAR24 & 89.4 & $2(15)$ & 53 & $4(75)$ & 43 & & \\
\hline OAR25 & 69.9 & $1(-)$ & 46 & $4(85)$ & 53 & & \\
\hline OAR26 & 71.1 & $4(97)$ & 55 & $4(95)$ & 62 & & \\
\hline
\end{tabular}

${ }^{1}$ sex-average, according to Maddox et al. (http://rubens.its.unimelb.edu.au/ jillm/ jill.htm); IC = information content.

in the French granddaughter designs, the dependent variable for each ram was the DYD [49], i.e. the average phenotype of the daughters was adjusted for environmental effects and additive genetic merit of the mates. Milk, fat and protein yields, and fat and protein contents were analysed. YD and DYD were obtained from the Spanish and French dairy sheep evaluation systems. 


\subsubsection{QTL detection methods}

QTL analysis was performed using multi-marker regression [21, 32]. Chromosome-wise significance thresholds were determined through 10000 phenotype permutations according to Churchill and Doerge [17].

\subsubsection{Results}

The QTL results for production traits are reported in Table III listing all tests significant at the chromosome-wise $\alpha_{c}=0.05$ type I error level. QTL were found for all dairy traits. Each detected QTL usually segregated in only two or three families. Most substitution effect estimates ranged from 0.4 to 1.5 phenotypic standard deviation units but the highest values were likely to have been overestimated due to the limited power of each design.

For the Sarda $\times$ Lacaune backcross ewes, the most significant results related to production were on OAR 3, OAR 16 and OAR 20. These three QTL were found to segregate in the same families and to affect milk, fat and protein yields in the same direction (Tab. III), in agreement with the known high genetic correlations (0.80 to 0.95$)$ between yields [2]. Moreover, QTL for the same traits have been reported on homologous bovine chromosomes [7]: BTA 20 (OAR 16) and BTA 23 (OAR 20). So far, the most significant QTL detected in this resource population was located on OAR 20 for fat content.

In the Churra sheep, a QTL was suggested in the telomeric region of OAR6 in the neighbourhood of the casein region (marker BM4311) affecting both protein percentage and milk yield. Two families were segregating in this region, one for protein percentage and the other for milk yield. Substitution effects clearly revealed distinct effects in the two families. In the first segregating family, the QTL produced a dilution-concentration effect of milk, as described in cattle $[27,48]$. On the contrary, the second segregating family showed pleiotropic effects on milk and protein yields as described by Kühn et al. [33] in cattle, but in a different chromosome region.

For the Lacaune and Manech breeds, in agreement with dairy cattle results $[5,18,27,48,51]$, QTL for fat content, protein content and protein yield were found on OAR9, OAR 5 and OAR 6, respectively (Tab. III). The most significant QTL was detected for fat content on OAR 9. This QTL was recently identified as a mutation in the DGATl gene on the homologous bovine chromosome (BTA 14) [28]. 
Table III. Significant QTL for production traits in the three QTL programmes, from $[11,13,20,23,47]$.

\begin{tabular}{|c|c|c|c|c|c|c|c|}
\hline$\overline{\mathrm{OAR}}$ & Programme $^{1}$ & Trait $^{2}$ & $\begin{array}{l}\text { Closest } \\
\text { marker }\end{array}$ & $\begin{array}{l}\text { Position } \\
\text { (cM) }\end{array}$ & $\begin{array}{l}\text { P-value } \\
(\%)\end{array}$ & $\begin{array}{l}\text { Informative } \\
\text { families }\end{array}$ & $\begin{array}{l}\text { QTL effect } \\
(\sigma \mathrm{p})\end{array}$ \\
\hline$\overline{1}$ & $1-\mathrm{BC}$ & $\begin{array}{l}\text { Protein } \\
\text { content }\end{array}$ & MCM058 & 98 & 0.5 & $1,6,8,10$ & $\begin{array}{l}0.46 /-0.71 /-0.45 / \\
-0.51\end{array}$ \\
\hline 5 & 3-GDD & $\begin{array}{l}\text { Protein } \\
\text { content }\end{array}$ & BMS2258 & 106 & 4.3 & $\mathrm{~B}, \mathrm{M}, \mathrm{N}$ & $0.74 / 1.18 / 0.79$ \\
\hline 3 & $1-\mathrm{BC}$ & Milk yield & BMC1009 & 168 & 0.12 & $4,6,10$ & $0.98 / 0.94 / 0.68$ \\
\hline & $1-B C$ & Fat yield & BMC1009 & 168 & 2.3 & $4,6,(10)$ & $0.82 / 0.93 /(0.44)$ \\
\hline & $1-\mathrm{BC}$ & Protein yield & BMC1009 & 166 & 0.05 & $4,6,(10)$ & $1.06 / 0.98 /(0.54)$ \\
\hline 6 & 2-DD & Milk yield & BM4311 & 128 & 3.5 & 4 & 0.52 \\
\hline & 2-DD & $\begin{array}{l}\text { Protein } \\
\text { content }\end{array}$ & BM4311 & 126 & 3.2 & 8 & 0.83 \\
\hline & 3-GDD & Protein yield & OARAE101 & 34 & 3.9 & $\mathrm{~B}, \mathrm{M}, \mathrm{N}$ & $-1.22 /-1.52 /-0.85$ \\
\hline 9 & 2-DD & Fat content & RHJI & 115 & 5.0 & 3,6 & $-0.43 / 0.41$ \\
\hline & 3-GDD & Fat content & CSSM66 & 12 & 0.38 & $\mathrm{G}, \mathrm{L}, \mathrm{M}$ & $-0.68 /-1.01 /-1.28$ \\
\hline 16 & 1-BC & Milk yield & MAF214 & 34 & 0.15 & $1,7,9$ & $0.51 /-0.57 / 1.06$ \\
\hline & $1-\mathrm{BC}$ & Fat yield & MAF214 & 32 & 0.37 & (1), 7,9 & $(0.38) /-0.52 / 1.06$ \\
\hline & $1-\mathrm{BC}$ & Protein yield & MAF214 & 32 & 0.59 & $1,(7), 9$ & $0.52 /(-0.44) / 1.01$ \\
\hline 20 & $1-\mathrm{BC}$ & Milk yield & BM1258 & 2 & 0.34 & $6,9,10$ & $-0.57 / 1.27 / 0.83$ \\
\hline & $1-B C$ & Fat yield & BM1258 & 0 & 0.68 & $6,9,10$ & $-0.56 / 1.05 / 0.69$ \\
\hline & $1-\mathrm{BC}$ & Protein yield & BM1258 & 2 & 1.04 & $6,9,10$ & $-0.49 / 1.26 / 0.76$ \\
\hline & $1-\mathrm{BC}$ & Fat content & OARH56 & 30 & 0.05 & $1,2,4,9$ & $\begin{array}{l}0.74 / 0.65 /-0.64 / \\
-0.65\end{array}$ \\
\hline
\end{tabular}

${ }^{1} 1$-BC $=$ Sarda $\times$ Lacaune backcross design; 2-DD $=$ Churra daughter design;

$3-\mathrm{GDD}=$ Lacaune or Manech granddaughter design.

${ }^{2}$ First lactation for $\mathrm{BC}$, all lactations for DD and GDD resource populations.

\subsection{Preliminary QTL results for conjugated linoleic acid content in milk fat}

The fatty acid composition of milk fat was measured twice for the Sarda $\times$ Lacaune backcross population at mid-second (847 records) and -third lactations (795 records). Most attention was paid to conjugated linoleic acid (CLA) content in the milk fat, because of its possible effect on human health. A large part of CLA in milk is produced in the mammary gland where vaccenic acid is desaturated by delta 9-desaturase. Thus QTL detection was carried out 
for CLA, and for the CLA/vaccenic acid ratio. In order to account for repeated records, a mixed model was used including the fixed effect of year*group of management and the random effects of ewes and sires. The effects of the 727 ewes with two records were used as phenotypes for QTL analysis. Significant QTL at the 5\% chromosome-wide level were found on OAR 4, OAR 14 and OAR 19 for CLA content in milk fat, and on OAR 4, OAR 6, OAR 14 and OAR 22 for the CLA/vaccenic acid ratio [14]. One QTL was found for the ratio on OAR 22 where the SCD gene encoding for delta 9-desaturase is located. A candidate gene approach for five genes, including SCD, is carried out on the same resource population.

\subsection{Other resource populations}

\subsubsection{In Spain}

There are two other projects involving the Latxa and the Manchega dairy sheep breeds. The Latxa QTL-mapping project uses a daughter design and "selective DNA pooling" in order to reduce the genotyping effort [44]. Preliminary results in the Latxa breed pinpointed two different regions of OAR 6 affecting milk traits: one coinciding with the region described in Churra, the other one in the telomeric end near the marker CSRD293 [44]. The Manchega QTL-mapping project uses a candidate-gene approach rather than a genome scan strategy (Serrano, personal communication).

\subsubsection{In Australia}

Another QTL mapping project, based on crossbreeding between Awassi and Merino sheep, started some years ago in Australia. It is linked to a dairy cattle research programme and the first results are expected soon (Raadsma, personal communication).

\section{CONCLUSION}

Milk protein polymorphisms have been considered as potential tools for selection of dairy ruminants. In dairy sheep, research on this topic is limited

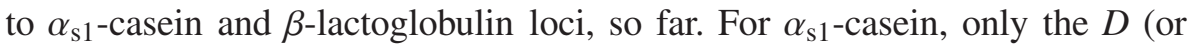
Welsh) variant has been related to a decrease in casein content and renneting 
properties. Nevertheless, its low frequency makes it nearly useless for selection. Similarly, the effects of $\beta$-lg polymorphism on dairy traits or milk technological properties are too inconsistent for implementing selection.

As a consequence, efforts have concentrated on QTL mapping projects. To our knowledge, most of them are regional projects in Mediterranean countries. Three of them in France, Italy, and Spain are part of the "Genesheepsafety" European project to investigate both production and functional traits. QTL have already been found for all dairy traits, the most significant being presently reported for fat content on OAR 9 and OAR 20. They are only preliminary results, based on the first lactation in the Sarda $\times$ Lacaune backcross population, on two chromosomes (OAR 6 and OAR 9) in the Churra sheep, and seven targeted chromosomal regions in the Lacaune and Manech granddaughter families. This project is continuing in three directions: the complete results of the genome scan of the Sarda $\times$ Lacaune backcross and Churra resource populations for all lactations will be published, the genome scan of the Lacaune and Manech resource populations will be completed, and the fine mapping of some QTL will begin. Nevertheless, the present preliminary results are promising and show that cattle QTL results can be partly transposed to sheep. Finally, QTL fine mapping will be a crucial step for dairy sheep. Due to the economical constraints in this species, only MAS based on population-wide linkage disequilibrium or, even better, GAS based on causal mutations, will be profitable.

\section{ACKNOWLEDGEMENTS}

The project, called "Genesheepsafety" project, was supported by a European contract (QLK5-2000-00656) of the European 5th Framework Programme.

\section{REFERENCES}

[1] Amigo L., Recio I., Ramos M., Genetic polymorphism of ovine milk proteins: its influence on technological properties of milk - A review, Dairy J. 10 (2000) 135-149.

[2] Barillet F., Genetics of Milk Production, Chap. 20, in: Piper I., Ruvinsky A. (Eds.), The Genetics of Sheep , CAB International, 1997, pp. 539-564.

[3] Barillet F., Rupp R., Mignon S., Astruc J.M., Jacquin M., Genetic analysis for mastitis resistance and milk somatic cell score in French Lacaune dairy sheep, Genet. Sel. Evol. 33 (2001) 397-415.

[4] Barillet F., Marie C., Jacquin M., Lagriffoul G., Astruc J.M., The French Lacaune dairy sheep breed: use in France and abroad in the last 40 years, Livest. Prod. Sci. 71 (2001) 17-29. 
[5] Boichard D., Grohs C., Bourgeois F., Cerqueira F., Faugeras R., Neau A., Rupp R., Amigues Y., Boscher M.Y., Levéziel H., Detection of genes influencing economic traits in three French dairy cattle breeds, Genet. Sel. Evol. 35 (2003) 77-101.

[6] Bolla P., Caroli A., Mezzelani A., Rizzi R., Pagnacco G., Fraghi A., Casu S., Milk protein markers and production in sheep, Anim. Genet. 20 (1989) 78-79.

[7] Bovenhuis H., Schrooten C., Quantitative trait loci for milk production traits in dairy cattle, in: Proc. 7th World Cong. Genet. Appl. Livest. Prod., Montpellier, 19-23 August 2002, Inra, Castanet-Tolosan, France, CD-Rom, Com. No. 09-07.

[8] Boyazoglu J.G., Flamant J.C., Mediterranean systems of animal production, in: Galaty J.G., Johnson D.L. (Eds.), The World of Pastoralism, 1990, pp. 353-393.

[9] Broad T.E., Burkin D.J., Cambridge L.M., Maher D.W., Lewis P.E., Ansari H.A., Pearce P.D., Jones C., Seven loci on human chromosome 4 map onto sheep chromosome 6: a proposal to restore the original nomenclature of this sheep chromosome, Mamm. Genome 5 (1994) 429-433.

[10] Caroli A., Bolla P., Spanu A., Piredda G., Fraghi A., Effect of $\beta$-lactoglobulin genotype on milk yield in the Sardinian sheep, in: Proc. 11 Cong. Nat. ASPA, Udine, 1995, Italy, pp. 181-182.

[11] Carta A., Barillet F., Allain D., Amigues Y., Bibé B., Bodin L., Casu S., Cribiu E.P., Elsen J.M., et al., QTL detection with genomic markers in a dairy sheep backcross Sarda $\times$ Lacaune resource population, in: Proc. 7th World Cong. Genet. Appl. Livest. Prod., Montpellier, 19-23 August 2002, Inra, CastanetTolosan, France, CD-Rom, Com. No 01-40.

[12] Carta A., De Candia M., Fois N., Ledda A., Ligios C., Molle S., Sanna S.R., Scala A., Casu S., in: "Datasheet on Sardanian breed - Animal Health and production compendium", CAB International, Oxon, UK, 2002.

[13] Carta A., Barillet F., Casu S., Cribiu E.P., Elsen J.M., Fraghi A., Mura L., Schibler L., A genome scan to detect QTL affecting dairy traits in a dairy sheep backcross Sarda $\times$ Lacaune population, in: Proc. 15 Cong. Nat. ASPA, Parma, 18-20 June, Italy, 2003, pp. 31-33.

[14] Carta A., Piredda G., Fiori M., Leroux C., Barillet F., A genome scan to detect QTL for CLA content in the milk fat of dairy sheep, in: 54th Annual Meeting of the European Association for Animal Production, 31 August-2 September, Roma, Italy, 2003, Book of Abstract, 89.

[15] Casu S., Deiana S., Tolu S., Carta A., Linear evaluation of udder morphology in Sarda dairy sheep: relationship with milk yield, in: Proc. Atti VIX Cong. Nat., SIPAOC, 1, 2000, pp. 195-198.

[16] Chianese L., Garro G., Mauriello R., Laezza P., Ferranti P., Addeo F., Occurrence of five $\alpha_{\mathrm{s} 1}$-casein variants in ovine milk, J. Dairy Res. 63 (1996) 49-59.

[17] Churchill G.A., Doerge R.W., Empirical threshold values for quantitative trait mapping, Genetics 138 (1994) 963-971.

[18] Coppieters W., Riquet J., Arranz J.J., Berzi P., Cambisano N., Grisart B., Karim L., Marcq F., Moreau L., Nezer C., Simon P., Vanmanshoven P., Wagenaar D., Georges M., A QTL with major effect on milk yield and composition maps to bovine chromosome 14, Mamm. Genome 9 (1998) 540-544. 
[19] De la Fuente L.F., Fernandez G., San Primitivo F., A linear evaluation system for udder traits in dairy ewes, Livest. Prod. Sci. 45 (1996) 171-178.

[20] Diez-Tascón C., Bayon Y., Arranz J.J., De La Fuente F., San Primitivo F., Mapping quantitative trait loci for milk production traits on ovine chromosome 6, J. Dairy Res. 68 (2001) 389-397.

[21] Elsen J.M., Mangin B., Goffinet B., Boichard D., Le Roy P., Alternative models for QTL detection in livestock. I. General information, Genet. Sel. Evol. 31 (1999) 213-224.

[22] El Saied U., Carriero J.A., La Fuente L.F., San Primitivo F., Genetic parameters of lactation cell counts and milk and protein yield in dairy ewes, J. Dairy Sci. 81 (1999) 2956-2961.

[23] El Zarei M.F., Arranz J.J., Gutierrez-Gil B., Bayon Y., de la Fuente L.F., San Primitivo F., Scanning chromosome 9 for QTL underlying milk production traits in Spanish Churra breed, in: Proc. 7th World Cong. Genet. Appl. Livest. Prod., Montpellier, 19-23 August 2002, Inra, Castanet-Tolosan, France, CDRom, Com. No 01-81.

[24] Erhardt G., Evidence for a third allele at the $\beta$-lactoglobulin $(\beta$-Lg) locus of sheep and its occurrence in different breeds, Anim. Genet. 20 (1989) 197-204.

[25] Fraghi A., Carta A., Pilla F., Sanna S.R., Piredda G., $\beta$-lactoglobulin polymorphism in Sarda dairy sheep, in: 47th Annual Meeting of the European Association for Animal Production, 1996, Den Haag, The Netherlands, Book of Abstract, 42.

[26] Gabiña D., Ugarte E., Santamaria P., The definition of breeding objectives in the Latxa dairy sheep breed, Options Méditerranéennes, FAO-CIHEAM, A43 (2000) 19-25.

[27] Georges M., Nielsen D., Mackinnon M., Mishra A., Okimoto R., Pasquino A.T., Sargeant L.S., Sorensen A., Steele M.R., Zhao X., Womack J.E., Hoeschele I., Mapping quantitative trait loci controlling milk production by exploiting progeny testing, Genetics 139 (1995) 907-920.

[28] Grisart B., Coppieters W., Farnir F., Karim L., Ford C., Berzi P., Cambisano N., Mni M., Reid S., Simon P., Spelman R., Georges M., Snell R., Positional candidate cloning of a QTL in dairy cattle: identification of a missense mutation in the bovine DGAT1 gene with major effect on milk yield and composition, Genome Res. 12 (2002) 222-231.

[29] Gutiérrez Gil B., Arranz J.J., Othmane M.H., de la Fuente L.F., San Primitivo F., Influencia del genotipo de la $\beta$-Lactoglobulina ovina sobre caracteres cualitativos y rendimiento quesero individual en la raza Churra, ITEA 22 (2001) 15-17.

[30] Hayes H., Petit E., Bouniol C., Popescu P., Localization of the $\alpha_{\mathrm{s} 2}$-casein gene (CASAS2) to the homeologous cattle, sheep, and goat chromosomes 4 by in situ hybridization, Cytogenet. Cell Genet. 64 (1993) 281-285.

[31] King J.B.W., The caseins of sheep's milk, in: Proceedings of the 10th European Conference on Animal Blood Groups and Biochemical Polymorphism, 1967, Inra, Paris, France, pp. 427-431.

[32] Knott S.A., Elsen J.M., Haley C.S., Methods for multiple marker mapping of quantitative trait loci in half-sib populations, Theor. Appl. Genet. 93 (1996) 71-80. 
[33] Kühn C., Freyer G., Weikard R., Goldammer T., Schwerin M., Detection of QTL for milk production traits in cattle by application of a specifically developed marker map of BAT6, Anim. Genet. 30 (1999) 333-340.

[34] Lopez-Galvez G., Ramos M., Martin-Alvarez P.J., Juarez M., Influence of milk protein polymorphism on cheese producing ability in the milk of Manchega ewes breed, in: Cheese Yield and Factors Affecting its Control, Int. Dairy Fed Seminar., Cork, 1993, pp. 167-173.

[35] Maddox J.F., Franklin I.R., Bottema C.D.K., De Silva U., Adelson D.L., Nattrass G., Identification of homologies between the sheep linkage map and maps of other species, in: Proc. XIX International Congress of Genetics, Melbourne, 2003, Australia, 1.B.0040 p. 103.

[36] Marie-Etancelin C., Casu S., Aurel M.R., Barillet F., Carta A., Deiana S., Jacquin M., Pailler F., Porte D., Tolus S., New tools to appraise udder morphology and milkability in dairy sheep, Options Méditerranéennes, FAO-CIHEAMIZCS, A55 (2002a) 71-80.

[37] Natale A., Sanna S.R., Oppia P., Carta A., Ligios S., Economic significance of some productive traits in Sarda sheep farming systems, Options Méditerranéennes, FAO-CIHEAM, A43 (2000) 27-31.

[38] Papoff C.M., Fraghi A., Piredda G., Pirisi A., Mauriello R., Battacone G., Pinna R.I., Chianese L., Distribution of ovine $\alpha_{\mathrm{s} 1}$-casein D variant in Sarda breed, Int. Dairy Fed. Bull. 9702 (1997) 308-310.

[39] Pellegrini O., Remeuf F., Rivemale M., Barillet F., Renneting properties of milk from individual ewes: influence of genetic and non-genetic variables, and relationship with physicochemical characteristics, J. Dairy Res. 64 (1997) 355-366.

[40] Pietrolà E., Carta A., Fraghi A., Piredda G., Pilla F., Effect of $\beta$-lactoglobulin locus on milk yield in Sarda ewes, Zoot. Nutr. Anim. 26 (2000) 131-135.

[41] Piredda G., Papoff C.M., Sanna S.R., Campus R.L., Influence of ovine $\alpha_{\mathrm{s} 1^{-}}$ casein genotype on the physicochemical and lactodynamographic characteristics of milk, Scienza e Tecnica Lattiero-Casearia 44 (1993) 135-143.

[42] Pirisi A., Piredda G., Papoff C.M., Di Salvo R., Pintus S., Garro G., Ferranti P., Chianese L., Effects of sheep $\alpha_{\mathrm{s} 1}$-casein CC, CD and DD genotypes on milk composition and cheesemaking properties, J. Dairy Res. 66 (1999) 409-419.

[43] Recio I., Fernandez-Fournier A., Martin-Alvarez P.J., Ramos M., $\beta$-lactoglobulin polymorphism in ovine breeds: influence on cheesemaking properties and milk composition, Lait 77 (1997) 259-265.

[44] Rendo F., Ugarte E., Lipkin E., Estonba A., Estudio preliminar de QTLs de producción lechera en el cromosoma 6 de la raza Latxa, in: Proc. Congr. Sociedad Esp. Genét. (2003) 89.

[45] Russo V., Davoli R., Migliori L., Genetic polymorphism of milk proteins in Massa and Sardinian ewes, Zootec. Nutr. Anim. 7 (1981) 421-428.

[46] Sanna S.R., Casu S., Carta A., Breeding programmes in dairy sheep, in: Proc. 7th World Cong. Genet. Appl. Livest. Prod., Montpellier, 19-23 August 2002, Inra, Castanet-Tolosan, France, CD-Rom, Com. No 01-34. 
[47] Schibler L., Roig A., Neau A., Amigues Y., Boscher M.Y., Cribiu E.P., Boichard D., Rupp R., Barillet F., Detection of QTL affecting milk production or somatic cell score in three French dairy sheep breeds by partial genotyping on seven chromosomes, in: Proc. 7th World Cong. Genet. Appl. Livest. Prod., Montpellier, 19-23 August 2002, Inra, Castanet-Tolosan, France, CDRom, Com. No 01-41.

[48] Spelman R.J., Coppieters W., Karim L., van Arendonk J.A., Bovenhuis H., Quantitative trait loci analysis for five milk production traits on chromosome six in the Dutch Holstein-Friesian population, Genetics 144 (1996) 1799-1808.

[49] Van Raden P.M., Wiggans G.R., Derivation, calculation and use of national animal model information, J. Dairy Sci.76 (1991) 2737-2746.

[50] Weller J.I., Kashi Y., Soller M., Power of daughter and granddaughter designs for determining linkage between marker loci and quantitative trait loci in dairy cattle, J. Dairy Sci. 73 (1990) 2525-2537.

[51] Zhang D., Boichard D., Hoeschele I., Ernst C., Eggen A., Murkve B., PfisterGenskow M., Witte L.A., Grognola F.E., Uimari P., Thaller G., Bishop M.D., Mapping quantitative trait loci for milk production and health of dairy cattle in a large outbred pedigree, Genetics 149 (1998) 1959-1973.

To access this journal online: www.edpsciences.org 
